\title{
Method of delivery of bone marrow stem cells to the articular joint influences their survival during arthroscopy
}

\author{
Reham Al Nono ${ }^{1,2}$, Gauthaman Kalamegam', Haneen Alsehli ${ }^{1,2}$, Farid Ahmed ${ }^{1}$, Mohammed Alkaff ${ }^{2}$, \\ Mohammed Abbas ${ }^{2}$, Wael Kafienah ${ }^{3}$, Faten Al Sayes ${ }^{4}$, Adeel Chaudhary ${ }^{1,5}$, Adel Abuzenadah ${ }^{1,5}$, \\ Mohammed Al Qahtani ${ }^{1,5}$, Mamdooh Gari ${ }^{1,5^{*}}$ \\ From 2nd International Genomic Medical Conference (IGMC 2013) \\ Jeddah, Kingdom of Saudi Arabia. 24-27 November 2013
}

\section{Background}

Cartilage poor capacity to regenerate can eventually lead to osteoarthritis. We aim to restore cartilage regeneration by introducing autologus bone marrow MSCs (BMMSCs) into the damaged joint using arthroscopy. The arthroscopic procedure involves variations in temperature either to supraphysiologic or subphysiologic levels following low-flow irrigation or cryotherapy respectively $[1,2]$. The aim of this study was to assess whether such temperature fluctuations would influence the viability and function of delivered BMMSCs and hence the outcome of the arthroscopic procedure.

\section{Materials and methods}

Primary cultures of human BMMSCs were assessed for their morphology (Phase contrast microscopy), cell proliferation (MTT assay) and surface marker analysis (FACS). Early passage of BMMSCs (P4; 1 x 106 cells/10 $\mathrm{mL}$ ) were used in two different configurations that reflect their potential method of delivery to the joint: a single cell-suspension (Group A) or a cell-pellet (Group B). The arthroscope with illumination was held in a fixed position such that it was suspended into the medium containing cell-suspension or cell-pellet in $50 \mathrm{~mL}$ tubes and different samples in both groups were incubated for 10, 20 or 30 minutes. The temperature increased with time from $27.6 \pm 0.14$ to $37.2 \pm 0.07$. The cell-suspension/cell-pellet were then gently mixed and $2 \times 10^{4}$ cells/well (24 well plate) were seeded. Cells were cultured under standard culture conditions $\left(37^{\circ} \mathrm{C}\right.$ in $5 \%$ atmospheric air) for $72 \mathrm{~h}$ and cell morphology and proliferation were assessed.

\section{Results}

BMMSCs showed characteristic fibroblastic morphology, proliferation and were positive for BMMSC related surface markers, namely CD73 (96.4\%), CD105 (76.1\%) and CD90 (29.4\%) (Figure 1A-C). They were negative for CD34 and CD45 (Figure-1C). In Group A, assessment of cell proliferation by MTT assay showed decrease by $2.04 \%$ and $63.27 \%$ at 20 and $30 \mathrm{~min}$, respectively, compared to control following arthroscopic exposure. However, only the decrease observed at $30 \mathrm{~min}$ was statistically significant (Figure 1D). In contrast, Group B showed statistically significant increases in cell numbers at $10 \mathrm{~min}(33.30 \%)$ and $20 \mathrm{~min}(23.33 \%)$ compared to the control (Figure 1E).

\section{Conclusions}

Long-term exposure of BMMSCs to the arthroscope as a single cell suspension or in pellets results in decreased cell viability. The pellet configuration seems to confer protection from temperature alterations during short periods of arthroscopic exposure. We conclude that the method of delivery of BMMSC to the joint could be detrimental to their survival and contribution to cartilage repair during arthroscopic procedure.

\footnotetext{
* Correspondence: mgari@kau.edu.sa

'Stem Cell Unit, Centre of Excellence in Genomic Medicine Research, King

Abdulaziz University, Jeddah, Kingdom of Saudi Arabia

Full list of author information is available at the end of the article
}

(c) 2014 Al Nono et al; licensee BioMed Central Ltd. This is an Open Access article distributed under the terms of the Creative Commons Attribution License (http://creativecommons.org/licenses/by/2.0), which permits unrestricted use, distribution, and reproduction in any medium, provided the original work is properly cited. 


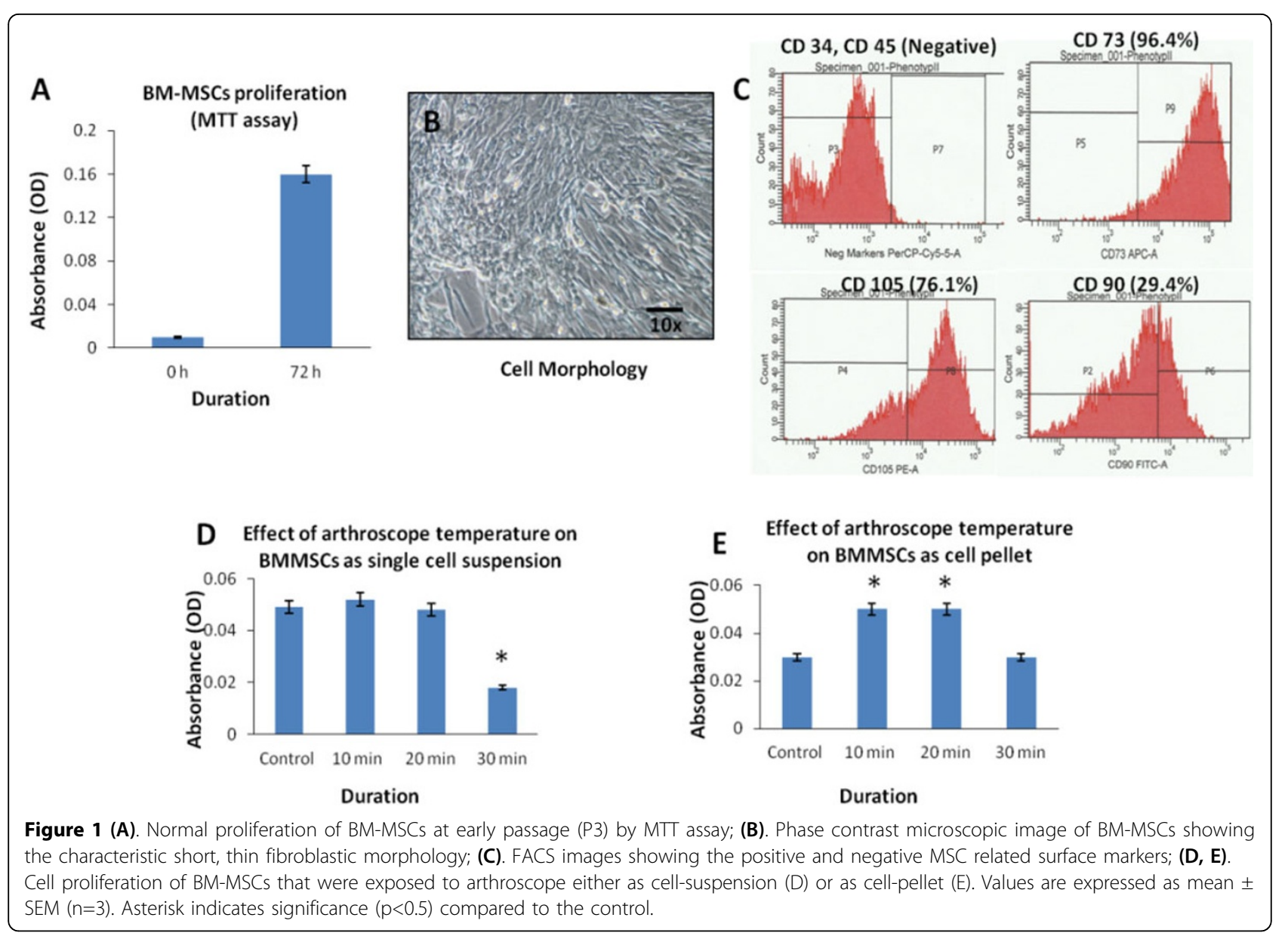

\section{Authors' details}

'Stem Cell Unit, Centre of Excellence in Genomic Medicine Research, King Abdulaziz University, Jeddah, Kingdom of Saudi Arabia. ${ }^{2}$ Department of Orthopaedic Surgery, Faculty of Medicine, King Abdulaziz University, Kingdom of Saudi Arabia. ${ }^{3}$ School of Cellular and Molecular Medicine, University of Bristol, UK. ${ }^{4}$ Department of Haematology, Faculty of Applied Medical Sciences, King Abdulaziz University, Kingdom of Saudi Arabia. ${ }^{5}$ Department of Medical Laboratory Technology, Faculty of Applied Medical Sciences, King Abdulaziz University, Jeddah, Kingdom of Saudi Arabia.

Published: 2 April 2014

\section{References}

1. Zaffagnini S, Allen AA, Suh JK, Fu FH: Temperature changes in the knee joint during arthroscopic surgery. Knee Surg Sports Traumatol ArthrosC 1996, 3(4):199-201.

2. Horstman $\mathrm{CL}$, McLaughlin RM: The use of radiofrequency energy during arthroscopic surgery and its effects on intra-articular tissues. Vet Comp Orthop Traumatol 2006, 19(2):65-71.

doi:10.1186/1471-2164-15-S2-P37

Cite this article as: Al Nono et al:: Method of delivery of bone marrow stem cells to the articular joint influences their survival during arthroscopy. BMC Genomics 2014 15(Suppl 2):P37.

\section{Submit your next manuscript to BioMed Central} and take full advantage of:

- Convenient online submission

- Thorough peer review

- No space constraints or color figure charges

- Immediate publication on acceptance

- Inclusion in PubMed, CAS, Scopus and Google Scholar

- Research which is freely available for redistribution 